\title{
History, Gender and the Colonial Moment: Castle Rackrent
}

\section{COLIN GRAHAM}

By-the-by, interrogatories artfully put may lead a suspicious reasoner, you know, always to your own conclusion. ${ }^{I}$

In Castle Rackrent (1800) the legislative merging of Ireland and Britain is figured in terms of gender, power and subversion. Edgeworth's novel, shifting uneasily on the pressured historical moment of Union, places the authoritative, textual, legal point of the colonial process in a complex intersection of cultural and gender identity, and its most extraordinary achievement is to produce a text in which it is textual and linguistic strategies, rather than commonly shared oppressions, which link gender and Ireland. Through 'sly civility', silences and feigned innocence, Castle Rackrent charts the nature of the Union in political terms and union in gender terms, its 'artful interrogations' pushing the reader unknowingly towards naively stated disturbances of established, complacent ideological discourses.

Edgeworth's text expresses its scepticism about the phenomenon of Union through an analogy which centres on a gendered notion of union. Union becomes both a marital and political act in Castle Rackrent and each union is viewed as a relationship of power in which dominance and counter-dominance co-exist, so that Castle Rackrent can eventually be read as a text which supports the notion that dominant discursive formations can be undercut without their knowledge. In order to substantiate this line of argument it will first be necessary to describe a critique of colonial textuality derived from the post-colonial critic Homi Bhabha. Bhabha's notion of 'sly civility' as a counter to colonial discourse can be traced in specific gendered terms onto Edgeworth's 'Essay on Self-Justification'. It can also lead to a view of Edgeworth's texts as potentially undermining gendered unions and to a reading of Castle Rackrent in which the examination of union/ Union uncovers resistances to a teleological notion of union/Union as a monologically healing process.

Using post-colonial criticism may be contentious enough in a Irish cultural setting. As Gerry Smyth has recently commented, its status is 'uncertain and its Literary Ladies, edited by Claire Connolly (London, 1994), p. 72. 
relationship with indigenous initiatives troubled'. ${ }^{2}$ It certainly needs to be adapted and exploited in the specific context of Ireland. Post-colonial criticism and the theoretical relationship between gender and post-colonialism constitute an infinitely wider issue than can be dealt with in this essay. A degree of applicability will be assumed in the following discussion of how the ideas of Homi Bhabha can be used to untangle some of the possibilities inherent in Edgeworth's text. Bhabha's essay 'Sly Civility' 3 will be used to discuss his notions of the doubleness of colonial/official discourses, how alternative, ironising forms can be inserted into the official. The aim here will be to turn these ideas onto the ways in which Castle Rackrent addresses gender and history at the same moment.

Bhabha's 'Sly Civility' has two main purposes. Firstly, it attempts to establish what he calls the 'ambivalence at the very origins of colonial authority'. ${ }^{4}$ In the broadest terms this can be seen as the gap between dominance and liberality in Western thought: the dichotomy between notions of the civilising mission of empire and all the ideologies and narratives of domination which go with it, on the one hand, and the trappings of freedom, individuality and humanism which are basic to Western thought and exist in tandem with dominance in an imperial context, on the other. Bhabha explores this 'space' in the predominant discourse in many ways, but perhaps his best example comes in his use of that arch utterer of imperial truths, Thomas Babington Macaulay. Bhabha quotes Macaulay's essay on Warren Hastings in which Macaulay says that Hastings' instructions, being interpreted, mean simply, "Be the father and the oppressor of the people; be just and unjust, moderate and rapacious."'s Of this piece of colonial advice, Bhabha says:

What is articulated in the doubleness of colonial discourse is not simply the violence of one powerful nation writing out the history of another. 'Be the father and the oppressor ... just and unjust' is a mode of contradictory utterance that ambivalently reinscribes, across differential power relations, both coloniser and colonised. For it reveals an agnostic uncertainty contained in the incompatibility of empire and nation; it puts on trial the very discourse of civility within which representative government claims its liberty and empire its ethics. ${ }^{6}$

The 'agnostic uncertainty' Bhabha describes in colonial discourse, where its selfcontradictions cannot close on each other, constitutes the space into which a counter-discourse can press its resistance. Having initially established the existence of this space, Bhabha moves on to his second major aim, to identify the means by which 'interpretation and misappropriation'7 can enter the space. Here Bhabha envisages the counter-discourse in the terms described by the title of his essay, 'Sly Civility'. He takes this phrase from an Archdeacon Potts writing in 1818 about Indian natives:

2 Gerry Smyth, 'The Past, the Post and the Utterly changed: Intellectual Responsibility and Irish Cultural Criticism' in Irish Studies Review, Io (1995), p. 27. 3 Homi K. Bhabha, 'Sly Civility' in The Location of Culture (London, 1994), pp. 93-101. 4 Ibid., p. 95. 5 Ibid. 6 Ibid., pp. $95-6$.

7 Ibid., p. 95 . 
If you urge them with their gross and unworthy misconceptions of the nature and the will of God, or the monstrous follies of their theology, they will turn it off with a sly civility perhaps, or with a popular and careless proverb. You may be told that 'heaven is wide place, and has a thousand gates'; and that their religion in one by which they hope to enter. ${ }^{8}$.

Bhabha suggests that this sly civility, a resistance which can never quite be entirely construed as resistance or acquiescence, deepens a crisis of paranoia in colonial discourse and widens the space in its doubleness. The importance of Bhabha's description of this psycho-political split is that it breaks the configuration of colonial interaction originally set up by Edward Said's notion of orientalism in which the west is, in effect, entirely dominant as a discourse. Textuality in the colonial context changes from being monolithic and complacent to being complex and unsettled, if still reflecting dominance.

The notion of sly civility can be used then in various ways. It has obvious political implications in that it suggests that colonial dominance does not necessarily imply a complete paucity of modes of resistance, though any modes of resistance included in the notion of sly civility will be restricted to oral and textual irony and slippages. For present purposes the idea of sly civility can be used to build a notion of textuality in which texts can be inscribed with both dominant and counter-discourses; in which colonial textuality can be self-parodying of its own dominance through the unwitting inclusion of sly civilities. Ireland was in a liminal position in the colonial encounter. It was on the threshold of what might be called entire colonisation, but its position was complicated by geography and blurred race issues. Such factors were central to the production of texts in Ireland which are not fixed in their cultural and discursive positions.

The notion of sly civility describes with some degree of accuracy the textual tactics at play in Castle Rackrent. These tactics, moreover, effect a paralleled linkage between the coloniser-colonised relationship and the gender relationships of marriage. The crucial factor in aligning colonial and gender relations in Edgeworth is the very notion of Union - as political event and as social marriage. Marriages are central to the narratives of Castle Rackrent, a text placed precariously on the moment of Union, and the novel's marriages are the points at which Edgeworth most obviously aligns cultural and sexual politics. But for the beginnings of Edgeworth's contemplation of sly civility in union/Union we can look back to her 'Essay on Self-Justification' (1785). In this deeply ironic and shifting text she describes the means by which women can subvert, counter, even control dominant male discourses without men's knowledge:

Nothing provokes an irascible man, interested in debate, and possessed of an opinion of his own eloquence, so much as to see the attention of his hearers 
go from him: you will then, when he flatters himself that he has just fixed your eye with his very best argument, suddenly grow absent. ${ }^{9}$

The tactics described here are those of the provoking frustration over which Bhabha sees colonists in India worrying. The authority of a discourse is undermined by the deliberate exploitation of the apparent incapacities of those subjected to it; for example, the 'feminine' inability to concentrate or the native's inability to discourse 'rationally' on religion. Yet these are also the very incapacities which justify the initial dominance. On either side of this paradox is the doubleness Bhabha describes. Edgeworth's 'Essay' alerts its readers to a gendered, subaltern consciousness which exists in the same social context as its dominant counterpart and which may even exist beside but without the knowledge of that which it undermines. It is a textual version of this sly civility of self-justification which is embedded in Castle Rackrent, and which makes it such a complex text in historical, cultural and gender terms.

The possibilities of this type of reading of Castle Rackrent are immense. What follows are examples of how the text can benefit from a Bhabha-derived analysis of its positioning of history and gender. These illustrate the possibilities for reading which Bhabha's ideas offer, yet none allows the theory to fit exactly or complacently as a epistemological framework for the text. This in turn confirms the notion implicit in Bhabha's essays that colonial discourse and its countering discourses co-exist in unpredictable and continually ironic ways.

Figuring the Act of Union as a marriage aligns gender questionably but temptingly alongside politico-cultural relations and allows the text to clash its component discourses in variant ways. The readings below imply that gender can exist on either the 'official' or 'unofficial' side of colonial discourse. Taken together, they suggest, in Edgeworth, a sceptical and radical examination of the potential of the political and gender Unions which circulate in Castle Rackrent.

\section{II}

As Marilyn Butler points out, ${ }^{\text {Io }}$ the 'Preface' to Castle Rackrent is, most likely, a work of collaboration between Maria Edgeworth and Richard Lovell Edgeworth. Given this knowledge it is tempting to view the work as the kind of dialogue of gendered sly civility which Bhabha transcribes in colonial terms in his essay. Such an analysis need not necessarily involve dissecting the language or authorship of the text in gender terms. As the 'Preface' puts it, 'there is much uncertainty even in the best authenticated ancient and modern histories'II and the 'Preface' itself replicates this textual ambiguity about authenticity, authority and written history.

9 Maria Edgeworth, 'An Essay on the Noble Science of Self-Justification', p. 70. ro Maria Edgeworth, Castle Rackrent and Ennui (Harmondsworth, 1992), p. 347. II Ibid., p. 61 . 
It thus ends with the apparent hope and potential of the Act of Union: 'When Ireland loses her identity by an union with Great Britain, she will look back with a smile of good-humoured complacency on the Sir Kits and Sir Condys of her former existence.' ${ }^{12}$ The teleology of assimilation and loss of identity here are already undermined by the 'Essay on Self-Justification', which has contorted the notion of the possibility of a post-union 'good-humoured smile'. At the very least the 'Essay' implies that the husband can never be certain of the intention of what appears as complacency and compliance. According to this view, the loss of identity is credible in only the most superficial of understandings of union/Union.

This leads to a consideration of the ways in which the 'Preface' deals with unofficial discourse, especially that of space Thady's voice. In a text which assumes an 'ignorant English reader', ${ }^{13}$ it is important to know if the 'Irishness' of the text is understood as a counterpart or a counter to 'Englishness'. The 'editor' of the 'Preface' says that $\mathrm{s} / \mathrm{he}$

had it once in contemplation to translate the language of Thady into plain English; but Thady's idiom is incapable of translation, and besides, the authenticity of his story would have been more exposed to doubt if it were not told in his own characteristic manner. ${ }^{14}$

The grammatical construction used here, especially the use of 'besides', suggests an elision of the knowledge of sly civility. By not translating Thady's idiom, its existence as something which may cast doubt on the 'complacent' loss of 'Irish' identity after Union is never, as the 'Preface' says, 'exposed to doubt'. Indeed it may be this which makes Thady untranslatable: not because he is insurgent - as an ideological or representative character he is certainly not - but because his otherness to 'plain English' is a reminder of the difficulty of union; and because this notion of misunderstood idiom in Union is tied, in gender and political terms, to the polite insurgency described in Edgeworth's 'Essay on Self-Justification'.

The 'Preface', which is at least in part a doubly-authored text, may then already signal the role of gender in simultaneously covering and exploiting the spaces opened by sly civility.The Union is presented in idealised terms in the 'Preface', though this presentation is at least potentially ironic. It is undercut by the notion of Thady's language as untranslatable. As for the process of the loss of Irish/'her' identity, it remains unexplained in a text that merely reinforces the difficulty associated with identity.

Given these enclosing presumptions about the text, understood through Bhabha's writings, Edgeworth's 'Essay' and the Edgeworths' 'Preface', the text can effectively be opened and examined in many ways. The sly civility exhibited in Castle Rackrent could be said to constitute the basis of the novel's ambiguities, ironies and humour; similarly, Tom Dunne identifies 'other aspects of the Irish stereotype - deviousness, flattery and dishonesty's in Castle Rackent, which in

12 Ibid., p. 63. 13 Ibid. 14 Ibid. My emphasis. and the Colonial Mind (Cork, 1984), p. 7 . 
themselves almost act as an anatomy of sly civility. And yet sly civility is more than a stage Irish stereotype in Castle Rackrent, it is the mobilisation of language and of silence, sometimes both, as a. way of speaking back. Like Edgeworth's advice to 'suddenly grow absent', sly civility relies on a curious and paradoxical ability to make less more. The moment of sly civility fills a gap in colonial discourse, but fills it with an unfathomable hollowness. In Bhabha's Archdeacon Potts' example of this disturbing linguistic reduction in the native's use of 'a popular and careless proverb', it is the correctness of the answer which is suspicious (the natives' linguistic competence is in itself worrying for Potts here). Richard Pococke, on his tour of Ireland in $\mathbf{1 7 5 2}$, finds himself having to explain away a similarly replete linguistic void: 'Asking here about the road, if it was hilly ? they told me it was, but that the hills were all level, by which I suppose they meant that they were not high. ${ }^{16}$ The exquisite moment of ambiguity here is quickly rationalised, but the indeterminacy it employs (whether deliberate or not on the part of the 'colonised') again reveals language and textuality to be central to sly civility's existence. The voice of 'here' (which is as specific as Pococke gets about who he asked) is dissolved as far as possible into the discourse of the traveller's prose but still a glimpse of the space it invokes remains.

Sly civility in Castle Rackrent is most readily identifiable in Thady, of course, and in his case it is deliberative silence masquerading as acquiescence which marks his relations with his masters. Most commonly this is expressed through the repeated phrase 'but I said nothing'. This first appears, appropriately enough, when the text's first 'union' is being discussed (the marriage of Sir Murtagh): 'it was a strange match for Sir Murtagh; the people in the country thought he demeaned himself greatly, but I said nothing' ${ }^{17}$ The immediate irony here is that Thady does not 'say nothing': the text itself is Thady saying everything, so that textually at least his sly civility parallels his longevity. Thady's 'but I said nothing' also takes us back, both grammatically and linguistically, to the 'Preface' and its 'Thady's idiom is incapable of translation, and besides'. Thady's 'but' and Edgeworth's 'besides' have equally unstable grammatical functions, perhaps because they both hinge on an uncertain assertion made either in or about Thady's 'idion'. Edgeworth, discussing Thady's voice, finds her own prose pre-echoing Thady's (and to an extent thus already aligning this tactic of sly civility with the writing of Castle Rackrent).

Thady's silence then is a tactic of sly civility and is employed at moments crucial to the narrative, and to union. Sir Condy's 'toss-up' to decide on his marriage partner is accompanied by Thady's usual apparent shrinking quietude: 'my heart was all as one as in my mouth when I say the halfpenny up in the air, but I said nothing at all; and when it came down, I was glad I had kept myself to myself' ' ${ }^{18}$ But this moment, like most others when Thady says 'nothing', is preceded by a more active subversion: 
'to prove it to you, Thady' says he, 'it's a toss up with me which I should marry this minute, her [Judy McQuirk] or Mr Moneygawl of Mount Juliet's town's daughter so it is.' 'Oh, boo! boo!' says I, making light of it, to see what he would go on to next; 'your honour's joking, to be sure; there's no compare between our poor Judy and Miss Isabella, who has a great fortune, they say.' ${ }^{19}$

Again, and as with the first use of 'but I said nothing', the moment of sly civility accompanies a decisive moment before union. Thady's role here is to push the narrative, moving the linear progression of novelistic history towards the marital act which should underpin the novelistic plot. And yet Thady turns this central narrative, social and ultimately political decision into an act of purest chance one which (having acted as catalyst) he observes in silence. Thady has here taken Edgeworth's advice to her 'fair readers' on dealing in their 'adversaries', men: 'Remember, all such speeches as these will lose above half their effect, if you cannot accompany them with the vacant stare, the insipid smile, the passive aspect of the humbly perverse. ${ }^{20}$

Gender and sly civility can be linked in more than tactical ways, though, in Castle Rackrent. One of the most obvious is through the metaphor and narrative device of marriage, which closes the 'Preface', as a projected mode of hope.Yet the text itself delineates a succession of failing marriages and unions. While not necessarily insisting on a continual parallel between Ireland and femininity in Union, a gender perspective on the text can focus on the difficulties, perhaps impossibilities of union. Sir Condy and Mrs Jane, for example, come to represent a marriage which the woman would never have entered into with a fuller knowledge:

my lady couldn't abide the smell of the whiskey punch. 'My dear', says [Condy], 'you liked it well enough before we were married, and why not now?' 'My dear,' said she, 'I never smelt it, or I assure you I should never have prevailed upon myself to marry you.' 'My dear, I am sorry you did not smell it, but we can't help that now,' returned my master, without putting himself in a passion, or going out of his way, but just fair and easy helped himself to another glass, and drank it off to her health. ${ }^{2 I}$

If it can be argued that this is merely narrativity, a 'novelistic' marriage without resonances through gender into politics, the footnote which accompanies the incarceration of Sir Kit's Jewish wife undeniably and explicitly pushes the political into the gender sphere. The 'editor' tells the story of a Colonel McGuire's wife who was imprisoned by her husband for over twenty years. The footnote ends:

I9 Ibid. My emphasis. 20 Maria Edgeworth, 'An Essay on the Noble Science of SelfJustification', p. 77. 2I Maria Edgeworth, Castle Rackrent and Ennui, pp. 9I-2. 
These circumstances may appear strange to the English reader; but there is no danger in the present times, that any individual should exercise such tyranny as Colonel McGuire's with impunity, the power now being all in the hands of government, and there being no possibility of obtaining from parliament an act of indemnity for any cruelties. ${ }^{22}$

Such a reassurance, which, like much of the text, is addressed with some irony to the English reader, rests of course on the authority of an act of parliament. Apart from a potentially deliberate and joking ambiguity about which parliament is referred to in I 800 , the authority which the editorial voice invests in this legislation echoes that hopeful note in the 'Preface' about the effects of the Act of Union. The same undermining process, an ironic interjection into a discourse of safety in legislation, must be seen at work here, and it begs the obvious question as to whether Sit Kit's behaviour would have been different after political Union and parliamentary legislation. Indeed it would be possible to argue that Sir Kit's treatment of his wife is not a pre-Union but a post-union/Union phenomenon, which comes about as much through the frictions of cultural as gender unions. His wife's Jewishness is continually emphasised by Thady's account, functioning mainly as a definition of her non-Irishness; as when she calls a turf stack 'a pile of black bricks' or describes a bog as 'a very ugly prospect' or laughs 'like one out of their right mind' when she hears the place name 'Allyballycarricko'shaughlin', as Sir Kit '[stands] by whistling all the while'. As Thady says, 'I verily believe she laid the corner stone of all her future misfortunes at that very instant; but I said no more, only looked at Sir Kit. ${ }^{23}$ Gender, cultural nationality and parliamentary act meet at this moment in the text, pressuring the notion of Union as benign change, implying dissent beyond the beginning of assimilation and allowing a space for the insertion of what remains outside the teleology and remit of the dominant.

Castle Rackrent not only plays with marriage as the act of union - it also looks forward to the end of union. (The Rackrents' marriages tend to dissolve simultaneously with their deaths.) Sir Murtagh's marriage (about which Thady has ominously 'said nothing') closes in a confusion over narrative time appropriate to the hiatus of Union in which Castle Rackrent is placed. (The hiatus at this point in the text is emphasised by surrounding footnotes, one of which suggests that, whereas in 'the last century' banshees visited Irish families, these visits have 'latterly' 'discontinued'; the next footnote, on the word 'childer' notes that this is how the word children was 'formerly pronounced' ${ }^{24}$ ) If this is (or could at least be seen as) celebratory subversion, it is certainly not 'civil' and Thady recognises it as such: 'But in a dispute about an abatement, my lady would have the last word, and Sir Murtagh grew mad; I was within hearing of the door, and now I wish I had made bold to step in. ${ }^{25}$ The 'abatement' is, of course, legalistically, a 'quashing' and allows, indeed insists on, a 'last word'. It is an act of foreclosure on marriage and union and prefigures Sir Murtagh's death; the Glossary, usually helpfully garrulous but 
here ironically tautologous, says only of 'Sir Murtage grew mad': 'Sir Murtagh grew angry ${ }^{26}$. Thady's silence is awkwardly complicit here with this disruption of civility, and is made inactive both by his listening and the very notion of a 'last word'.

While Sir Murtagh's death and marriage end almost before they are over, other Rackrent unions have equally ludicrous, and confused beginnings and terminations: Sir Condy's begins with the toss of a coin and ends with a freak accident (he believes), while his life ends with a staged wake. Sir Kit's 'second' marriage is on the verge of being decided by duel when one of his opponents gets his wooden leg 'stuck fast' in a 'ploughed field', ${ }^{27}$ as if the text wishes to veer away from direct confrontation and towards the pleasure of farcical civility (the two parties 'shook hands cordially, and went home to dinner together' ${ }^{28}$ ). Sir Kit himself is killed and his wife lives. Having from her 'confinement' been much obliged to Sir Kit and drunk, in absentia, 'the company's health', Lady Rackrent, as Thady notes, 'got surprisingly well after my master's decease'. ${ }^{29}$ Thady's 'surprise' is inherent in his sly civility: it is dutifully and superficially innocent but contains an understanding complicity with 'the Jew Lady Rackrent', who survives her imprisonment through her ability to fill the fake politeness of her husband's address with a countering weighty politeness of her own. Thady cuts off any sympathy he has for Lady Rackrent with civility at her expense in the staffering naivete of saying: 'she had taken an unaccountable prejudice against the country'. ${ }^{30}$

Thady's narrative style is thus attuned to contain the quiet carnivalesque it sees in acts of union, including civility and growing absences, with pleasurable ease; but against this it sets the disjunction caused by direct incivility. For Thady himself, Jason is disturbing, most obviously because he usurps the social order; equally Jason's disturbing tendencies arise from his increasing confidence in moving outside the power relations which necessitate sly civility:

Now I could not bear to hear Jason giving out after this manner against the family, and twenty people standing by in the street ... I could scarcely believe my own old eyes, or the spectacles with which I read it, when I was shown my son Jason's name joined in the costodiam ... so I said nothing, but just looked on to see how it would all end. ${ }^{31}$

Jason's 'giving out' in this public way is ironically juxtaposed to the novel itself but what it lacks is irony and civility. Jason's name is 'joined in the custodiam', another affront, and another perversion of 'union'. Thady's response is now almost stock, and, since the unspoken nature of his sly civility has been broken by Jason's directness, Thady's response of saying nothing seems increasingly hollow.

This episode precedes the ending of Sir Condy's marriage to Bella, and in the latter's conclusion there is a breaking of the strategies of 'self-justification' of gendered relations recommended by Edgeworth. Bella, having told Condy to 
shave, sees him do so: 'But she took no notice, but went on reading.'32 In a way this mimics Thady's 'but I said nothing'; however this follows direct instruction and acquiescence by the husband. The double 'but' serves as an over-emphasis and differentiates it from the subtlety of Thady's civility; this is followed by Bella questioning the very basis of her marriage to Condy.

So for Thady and Castle Rackrent's sly civility, and the tactic of growing absent, there is an alternative figuration of gender and union/Union which builds in the text: once the power relations which produce sly civility are challenged or changed (as with Jason) or made explicit (as with Bella), the possibilities of sly civility are altered too. And yet Thady's narrative itself is intent on collapsing these challenges into its own sly civility - Jason's triumph is achieved through the tactics and strategies he has learnt from his father. And Jason himself is ultimately caught up in the narrative innocence which 'fools' the 'Editor' of Castle Rackrent who at the end of the text says:

The Editor could have readily made the catastrophe of Sir Condy's history more dramatic and more pathetic, if he thought it allowable to varnish the plain round tale of faithful Thady. He lays it before the English reader as a specimen of manners and character, which are, perhaps, unknown in England. Indeed the domestic habits of no nation in Europe were less known to the English than those of her sister country, till within these few years. ${ }^{33}$

Thady is given his ultimate audience and the tag he needs to play it: 'honest Thady' is now 'faithful Thady'. At this crucial moment of Union the 'domestic' is rendered through a series of gendered unions which are 'allowed' to the sly civility of Thady; Ireland is rendered to 'the English reader' by a narrator capable, as the 'Editor' goes on to say, of combining 'simplicity, cunning ... shrewdness and blunder'. ${ }^{34}$ Where the text toys with the possibility that sly civility is redundant (since Jason ceases to need to 'grow absent' into silence), it finally leaves the reader at the mercy of a narrator who has made slyly civil his own power relations, and has delineated union/Union in terms of tragedy, farce, mistimed narratives and death.

\section{III}

In Castle Rackrent the cultural politics of metaphoric marriages becomes laden with the possibility of sly civility. The text pushes towards the notion of marriage as the appropriate construction for understanding the union/Union, yet ironises its own expressed belief in the ability of union to facilitate a loss of identity tantamount to a discursive monologism. Its notion of the untranslatable idiom, necessary for a treasured 'authenticity', can be used to place its delineation of the cracks in colonial, dominant discourses in the context of Bhabha's idea of the double articulation of colonialism and the nature of sly civility. 
Edgeworth's text expresses something implied but unexplored in Bhabha's essay: ${ }^{35}$ the double-facedness of the coloniser may be seen from outside the coloniser's discourse, but if seen it cannot be fully, dialogically articulated by the colonised. It can only be mimicked, parodied in sly civility. A knowledge of the space between the double-face of colonialism can only be voiced where the coloniser is deaf to it. And yet however small this space may be, any insertion into this space begins the process of undermining and exploding the authority of colonialism. To borrow the metaphor Edgeworth uses in her 'Essay on SelfJustification', when advising a woman on how to gain the sympathy of bystanders when confronted by her irascible husband, 'the simple scratching of a pick-axe, properly applied to certain veins in a mine, will cause the most dreadful explosions'. ${ }^{36}$ Reading Castle Rackrent in this way reorientates it as an ironic, multivoiced text. It certainly serves to contradict one historian's literal reading of the novel as one in which Edgeworth was 'careful to assure her [English] readers that the events she unfolded bore no resemblance to the Ireland of her own time'. ${ }^{37}$ Castle Rackrent pressurises the notion and the moment of Union through a gendered understanding of cultural interaction; against the colonial discourse which implies a loss of identity, it pits an awareness of dissent which is dangerous for its untranslatable, slyly civil qualities.

35 Bhabha expands on aspects of the theories central to 'Sly Civility' in 'Signs Taken for Wonders: Questions of Ambivalence and Authority Under a Tree Outside Delhi, May I8I7' also in The Location of Culture, pp. I02-22. 36 Edgeworth, 'An Essay on the Noble Science of Self-Justification', p. 70. 37 D. George Boyce, Nineteenth-Century Ireland: The Search for Stability (Dublin, 1990), p. 22. 